\title{
Spirituality and anti-Western rhetoric in Uzbekistan in the early 2000s: the consequences of international misrecognition
}

\section{Bernardo Teles Fazendeiro}

To cite this article: Bernardo Teles Fazendeiro (2018) Spirituality and anti-Western rhetoric in Uzbekistan in the early 2000s: the consequences of international misrecognition, Post-Soviet Affairs, 34:4, 228-245, DOI: 10.1080/1060586X.2018.1468686

To link to this article: https://doi.org/10.1080/1060586X.2018.1468686

曲 Published online: 08 May 2018.

Submit your article to this journal $\sqsubset$

凹 Article views: 139

View Crossmark data $\sqsubset$ 


\title{
Spirituality and anti-Western rhetoric in Uzbekistan in the early 2000s: the consequences of international misrecognition
}

\author{
Bernardo Teles Fazendeiro \\ Centre for Social Studies, University of Coimbra, Coimbra, Portugal
}

\begin{abstract}
References to the spirituality-morality (ma'naviyat) of the Uzbek people increased substantially throughout the course of Islam Karimov's years in office as the President of Uzbekistan. Uzbek values were presented as qualities springing from the country's supposedly unique civilizational heritage, cast as something distinct from "Western" civilizational norms and practice. This source of distinctiveness, however, soon gave way to a type of exclusionary discourse in the early 2000s, centered on clearly differentiating Uzbekistan from the "West." This essay provides a lens through which to understand the phenomenon, arguing that international recognition of status partly accounts for the rise in the particularly anti-Western variant of Karimov's rhetoric. Authorities in Uzbekistan, not unlike in Russia, built their foreign policy on the need to secure the country's (allegedly) important status in the international arena; anti-Western rhetoric arose as a response to misrecognition, as it evaded appeals to equality of status and legitimized growing isolationism. The essay reviews the origins of that rhetoric, the meaning of recognition, and the backdrop against which anti-Western moralizing rhetoric arose in Uzbekistan's international engagement. It also concludes with a brief assessment of how that rhetoric might affect (or not) the foreign policy of Uzbekistan's new president, Shavkat Mirziyoyev.
\end{abstract}

\section{ARTICLE HISTORY}

Received 28 November 2017 Accepted 5 April 2018

\section{KEYWORDS}

Uzbekistan; foreign policy; rhetoric; spirituality; civilization

Over Uzbekistan's 25 years of independence, President Islam Karimov referred increasingly to spirituality-morality (ma'naviyat - henceforth SM). By spiritual moralizing rhetoric, I mean talking or writing about the cultural/civilizational status of a certain people, their traditions, practices, and history, and especially how all those combined traits are a source of collective distinctiveness. Taken to the extreme, however, alluding to SM may reach a point where "unique" practices become not only a source of distinction, but also of exclusion. This is what happened to Uzbekistan in the early 2000s; Karimov set Uzbekistan, a country of the "East," apart from its counterparts in the "West":

[An] English intelligence officer said in his time that the East is the East and the West is the West. I will not go into details but he said something to the effect that the West and the East would never come together. It was said back in the 19th century. (quoted in BBC Monitoring International Reports 2005)

For Karimov to have taken issue with the "West" in the early 2000s is hardly surprising in light of the international pressure to which Uzbekistan was submitted during the "War on Terror" (2001-2003), the so-called "Color Revolutions" in the former Soviet space (2003, 2004, 2005), and the Andijan massacre (2005). There is nevertheless a difference between just criticizing the West and outright excluding it from 
the political, moral, and cultural arenas. Karimov had in fact condemned all sorts of individuals, groups and states-from journalists to the Russian Government - throughout his long tenure in office. He had not, however, taken all those objects of condemnation to be adverse to Uzbek SM. Though Karimov, as shown below, did systematically refer to the "Eastern" or "Oriental" attributes of the Uzbek nation, which was a continuation of former Soviet policy, he had not necessarily cast them as a source of-or reason for-political exclusion. On the contrary, upon coming to office, Karimov positioned himself as a non-ideological and anti-nationalist technocrat, an admirer of the West who actively sought collaboration:"cooperation with the Western world paves the way for high technology, investment in the basic sectors of industry, and the comprehensive utilization of natural resources" (Karimov 1992b, 32).The anti-Western variant of SM results, I argue, from accumulated tensions over Karimov's inability to secure international recognition of status. Though the criticism to which the government was subjected in the early 2000s mattered, the grievances began earlier, right after Uzbekistan's independence in 1991. The Uzbek authorities had set themselves the task of achieving a status equal to all other international actors, an expectation that proved difficult to fulfill. In effect, lack of recognition led to growing resentment, with Karimov increasingly highlighting the underlying spiritual, moral differences-as opposed to the similarities - between Uzbekistan and the so-called "West." In doing so, he was able to justify growing isolationism and downplay the promise of equality of status; Uzbekistan could no longer be deemed equal to others by virtue of holding a unique moral and cultural outlook. This phenomenon is not unique to Central Asia, however, as references to cultural, moralizing, and civilizational differences have grown sharply in a number of other former Soviet states, especially in Russia (Baranovsky 2000; Selezneva 2002; Laruelle 2009, 2010; Thorun 2009; Tsygankov 2012; Neumann 2016; Tsygankov 2016; White and Feklyunina 2014). Looking at Uzbekistan, however, offers an additional prism through which to understand the rise of resentment and the consequences of international misrecognition (Larson and Shevchenko 2010; Tsygankov 2012, 2015, 2016; Heller and Wolf 2014). It also points to how Uzbek SM may potentially play out during the mandate of Uzbekistan's new president, Shavkat Mirziyoyev.

In order to make sense of political and moralizing exclusion, it is important to note that I refer to the West (G'arb as it is otherwise known in Uzbek) in the same way Karimov spoke of it, as a linguistic catchphrase with which to depict (sometimes deprecate) a number of actors, practices, and ideas. Though the West can hardly be considered a single actor in its own right (if an actor at all), it encompasses, according to Karimov, a world of liberal principles—such as the promotion of democracy, market reform, and human rights - in conjunction with the actors who promote those principles: the United States (US), European Union (EU), International Monetary Fund (IMF), World Bank, and so on. The East (Sharq), by contrast, is often taken as the direct opposite of the West, especially with regard to social habits.

It is also worth bearing in mind that this essay is centered on SM rather than on broadly defined nationalism. While references to morals, authenticity, and "Uzbekness" arguably fall under the prism of exclusionary-sometimes ethnically driven-nationalism, I avoid the concept altogether in order to side-step existing debates about its actual theoretical meaning and empirical manifestation. In addressing the appearance and surge of anti-Western SM in the early 2000s, this essay is not meant to suggest that nationalism increased during the same period. Despite Karimov's use of exclusionary rhetoric, determined to separate Uzbekistan from the West, nationalism was always invoked in some form or another (civic, ethnic, or other) throughout Uzbekistan's period of independence. Uzbek authorities were intent on fostering some idea of national identity or nationhood from the beginning (Adams 2010), and so references to Uzbek SM already presume the existence of some form of nationalism. Moreover, depending on the theoretical perspective, the concept of nationalism varies substantially. It can be conceptualized as an elite-driven project or else posited as an everyday struggle for meaning and belonging (Megoran 2017). This essay is nevertheless concerned with the authorities' use of such rhetoric in the effort to legitimate Uzbekistan's position in world affairs. Karimov, as the ruling President of Uzbekistan for 25 years, offers an especially important lens through which to understand the types of policies, slogans, and approaches that were deemed appropriate (or not) for the enactment of policy (Spechler and Spechler 2009). 
To build my argument, l examine the meaning of Uzbek SM in relation to Karimov's broader political rhetoric. References to SM increased in prominence throughout the 1990s, but were not-following Soviet practice-deployed for the sake of pre-emptively demonizing the West. Anti-Western SM only developed, I argue, in the 2000s. The essay then covers the conceptual links between resentment, respect, and international (mis)recognition, showing the extent to which Uzbek authorities considered themselves worthy of international status. I show thereafter the incidents that denigrated Uzbekistani equality of status over time, and conclude with a brief discussion of the effects of SM on Uzbekistani political discourse, including how it might affect Mirziyoyev's political agenda. My essay relies mainly on Karimov's speeches and his published works. I also use "Uzbek" when alluding to ideas and concepts that encompass a specific, ethnically driven aim, and "Uzbekistani" when speaking of a more inclusive territorial entity, which is how Karimov sometimes depicted Uzbekistan on the international stage.

\section{Uzbek SM (ma'naviyat)}

Uzbek SM became a staple feature of Karimov's political rhetoric soon after Uzbekistan became independent in 1991. As a loose assemblage of ideas and norms, it is a concept that is difficult to pin down, with Karimov $(2008,12)$ himself admitting to the existence of several versions of SM, depending on how they are individually interpreted. Conceptual intricacies aside, publications approved by the authorities outlined the concept, referring to it as "a totality of philosophical, legal, aesthetic, artistic, ethical, religious ideas and concepts. Spirituality-Morality (ma'anaviyat) is ideologically close to the concept of conscience or thought (tafakkur), and they both require each other" (Abdullayev et al. 2009, 200). In addition, SM allegedly results from a particular historical-cultural experience:

If we glance at the way of life and thought of our people, it does not look like others; we will see a number of unique features which were formed over a thousand years, not only in behavior, but also in the elements of our lives. (Karimov 2008, 6).

Uzbek SM, under Karimov, is rooted in an essentialist and teleological reading of history. It consists of an immutable set of practices—such as religion — that (supposedly) resist all sorts of foreign and alien influences and which therefore still shape Uzbek society: "despite the brutal persecutions, our people have remained loyal to their sacred religion. This alone is a testimony to the fact that religion is never extinguished by a human, nation or society" (Karimov 2008, 59). This allows Karimov to hearken back to Uzbekistan's so-called great ancestors, speaking of them as sources of ethical wisdom, despite many of those thinkers actually living centuries apart:

The names of illustrious erudite personalities have been preserved in the hearts and minds of our people: Beruni, Al-Kwarazmi, Abu Ali ibn-Sino, Imam Al-Bukhari, At-Termezi, Akhmad Yassavi, Ulugh-Bek, Navoi and other creative personalities of world renown were of profound spirituality (Karimov 1992b, 63).

Moreover, the Soviet and Russian imperial experiences were deemed distortions of proper Uzbek SM, a claim that Karimov repeated throughout his long tenure in office (Karimov 1998, 2008). This claim was nonetheless similar to other post-colonial discourses echoed throughout Central Asia, often intent on depicting the Soviet period as oppressive (Adams 2008; Heathershaw 2010; Kudaibergenova 2016). These Soviet distortions were considered dangerous by Karimov for the reason that SM was to remain pure, as it was as essential as any biological desire: "human beings need spirituality like they need to breathe air and drink water." (Karimov 1992b, 62).

Beyond their historical, teleological underpinnings, geographical/cultural constructs were deemed important to laying down the foundations of Uzbek SM, which was allegedly constituted by a particular cultural/spatial experience. As persuasively demonstrated by Nick Megoran (2017), geographical constructs are essential to defining independent Uzbekistan and its ideology of independence or self-reliance. For Karimov $(1998,85)$, the East (however ambiguous the term) is where Uzbek SM comes from: "inherited cultural values have been a powerful source of spirituality for the peoples of the East for millennia," with Uzbekistan (apparently) having kept the essence of those norms through time. ${ }^{1}$ Indeed, those norms set the basis for a number of distinctive morals: "following the best traditions of 
the Oriental civilizations, Uzbekistan is widely known for hospitality and friendliness" (Karimov 1992b, 57). Such features, along with family-centered practices, respect for elders and local communities (otherwise known as mahallahs) were supposedly the core attributes of Uzbek SM and thus its way of life (Allworth 1990; Karimov 2008).

The irony, however, is that this initial version of Uzbek SM, while anti-Soviet in content, was clearly Soviet in form. Indeed, SM (or dukhovnost' in Russian) constituted a key aspect of Stalin's conception of nationhood. For Stalin (1913), "nations differ not only in their conditions of life, but also in spiritual complexion, which manifests itself in peculiarities of national culture." Following this conception of nationality, the Soviet Union sought to foster national revival, albeit in a way compatible with inter-ethnic harmony and opposed to isolationism and exclusionary nationalism (Slezkine 1994; Hirsch 2000; Martin 2001). To that end, all the republics were supposed to abide by the tenets of the USSR's nationalities policy, with many of its national leaders echoing these claims. Sharaf Rashidov-the long-term Secretary General of the Uzbek SSR's Communist Party (1959-1983)—stated, for example, that Soviet nationalities policy engendered (or at least was supposed to engender) both unity and distinctiveness among peoples: "there are no contradictions between national and international interests of the peoples in our country: they coincide and merge" (Rashidov 1978, 88).

In like manner, Karimov's initial references to SM hardly signaled a sudden or even substantial departure from Soviet policy. Referring to SM was simply meant to foster national identity, without, however, fostering enmity and political exclusion. Indeed, speaking of the Uzbeks as Eastern as opposed to Western was not novel, nor meant to be anything other than a mark of distinctiveness. So ingrained was this mode of thinking that even Russia's first President, Boris Yeltsin, described Karimov on the basis of his "Easternness": "I remember ... Islam Karimov, president of Uzbekistan, a wonderful person, a subtle man in the Oriental tradition" (Yeltsin 2000, 249).

\section{Internationalist (Soviet) SM}

SM became an important facet of Uzbekistan's domestic politics, very much in line with the government's determination to foster a particular national identity. It proved to be a powerful slogan, allowing the authorities to crack down on perceived immoral practices, from the way in which pop singers were dressed to the types of music made available to the youth. ${ }^{2}$ Uzbek SM was subsequently institutionalized in 1994 via the center for Spirituality-Morality and Enlightenment (Ma'naviyat va Ma'rifat) (Lex.uz 1994). That said, as already mentioned, Uzbek SM was not initially presented as a mode of political exclusion. It was not meant (at least in the beginning) to cast other cultural influences, such as Western norms, as incompatible with the Uzbek way of life. It was not even a core aspect of Karimov's rhetoric, which remained largely technocratic for most of the late 1980s and early 1990s.

\section{SM in view of Karimov's broader discourse}

No longer part of a multinational empire such as the USSR, both the government and Uzbek cultural elites increasingly paid heed to SM for the sake of promoting a distinctive national identity (Adams 2010). This was an important, albeit peripheral, goal as far as Uzbekistan's President was concerned. In the aftermath of independence, Karimov preferred rather to speak of his technocratic expertise. He did so partly to dismiss the opposition, particularly members of the Erk and Birlik parties, many of whom were keen on reviving Uzbek cultural authenticity (Markowitz 2009). ${ }^{3}$ To that effect, technocratic management was the actual cornerstone of Karimov's political argumentation throughout most of the 1990s (March 2003; Spechler 2008; Spechler and Spechler 2009). It justified why Uzbekistan was delaying rapid reform, unlike the other former Soviet republics. Hence, Karimov centered his legitimacy on revealing the problematic consequences of a sudden transition rather than on showcasing the republic's cultural distinctiveness. He often captured this approach by way of specific catchphrases, such as "don't destroy the old before building a new house" (yangi uy qurmay turib, eskisini buzmang) (Karimov 1993b), which was often accompanied by the claim that economics superseded politics: 
First people seek a full stomach, to be fed and well clothed. First the economy, then politics (avaal iqtisod, keyin siyosat), for there is the saying: the hungry man listens to music with his stomach. (Karimov 1993a, 62)

Spiritual needs, albeit relevant, were far from Karimov's agenda in the wake of independence and, most importantly, far from being the means by which the government cast aside its opponents. Karimov criticized opponents on the grounds of their inept technocratic management and also on their alleged fixation with ideology, nationalism, and culture: "I personally find it hard to deal with politicians who fail to consider the economic consequences of each step they take" (quoted in BBC Summary of World Broadcasts 1993a). By the same token, Karimov did not initially position the West, liberalism, and globalization as "un-Uzbek." On the contrary, striving for Western principles and standards of living were the government's main goals for the foreseeable future. Uzbek SM was only invoked with a view to reviving Uzbek culture and regulating conduct; it was not meant to isolate Uzbekistan. Although, as shown below, the authorities did criticize Western individuals and states for pressuring Uzbekistan to reform quickly, they still referred to democracy and a market economy as the core (albeit long-term) goals of the country: "the political and administrative organization of the reformed society must guarantee the individual's freedom of choice in political, economic and social realms" (Karimov 1992b, 14). All such principles were also enshrined in Uzbekistan's constitution. ${ }^{4}$ But authoritarianism and central governmental guidance were necessary, so Karimov argued, in order to prevent Uzbekistan from deviating:"firmness, an authoritarian approach, if you wish, in realization of the chartered policy is needed in the transition period" (quoted in BBC Summary of World Broadcasts 1993b).

All in all, references to Uzbek SM were initially internationalist rather than exclusionary in scope. They did not necessarily target the West, nor any other specific set of ideas or actors. This Soviet conception did not, however, prove resilient, as Karimov gradually invoked SM not only to signify cultural distinctiveness, but also to exclude others.

\section{From cultural distinctiveness to political exclusion}

One way in which to detect the increased prominence of SM is to look at Karimov's published works, many of which justified the overall direction of governmental policy. Whereas in one of Karimov's early (1992b) publications, Uzbekistan: The Road of Independence and Progress, references to SM appear almost as an epilogue, only for the sake of reviving the historical dignity of the Uzbek people. Yet in his 1998 publication, Uzbekistan: On the Threshold of the Twenty-First Century, SM appears at the beginning of Part Il of the book, depicted as an important means by which to dispel threats to Uzbekistan's independence.

The surrounding international and domestic contexts account, in part, for the discursive shift. Uzbekistan had at the time witnessed the consolidation of the Taliban in Afghanistan, the creation of the Islamic Movement of Uzbekistan and a civil war in neighboring Tajikistan. To avoid potentially negative spillovers, Karimov refers ever more pervasively to "alien" and extremist practices, pointing to their relation to instability:

[There was] the further danger of a growth in extremist opposition, which, in essence could be an opposition to spirituality. Its political aspirations are a mixture of aggressive nationalism, religious intolerance and a pathological hatred of everything that is "alien." (Karimov 1998, 86)

SM became an instrument by which to curb negative influences to Uzbekistani stability and security. It did not, however, imply a major shift in the state's overall policy, as the government remained concentrated on its gradualist, technocratic approach to political economic reform, an approach that was meant to foster Western-style democracy in the future: "as its main priority Uzbekistan chose the values of democracy and personal freedoms, the provision of human rights, and the creation of a free market economy" (Karimov 1998, 95). Karimov also continued to push for greater dialog with the Western and globalizing world: "wide international contacts have not only created favourable ground for a deeper study of world culture and assimilation of universal values" (Karimov 1998, 91-92). The discursive shift toward isolationism and anti-Westernism would only occur in the early 2000 s. 


\section{The East and West cannot meet}

Karimov published an entire book in 2008 on the unique nature of Uzbek SM entitled High SpiritualityMorality: An Invincible Force (Yuksak Ma'naviyat: Yengilmas Kuch) in which the "Eastern" characteristics of Uzbek SM were cast as being under threat from globalization. This position was in stark contrast to Karimov's earlier claim that Uzbekistan had much to gain from engaging with the West and with globalization in general. In fact, being Eastern became more than a harbinger of cultural distinctiveness; it now signified irreconcilable differences between Uzbekistan and the West. The very Western values in which the authorities had vested considerable political importance were now presented as political threats to the Uzbek way of life, with Karimov $(2008,7)$ underscoring the stark differences in lifestyles and morals between East and West: "in the Western world (G'arb olamida) individualism rather than communal life (jamoaviylik) can be observed in the people's way of life; the tendencies of private interest (shaxsiy manfaat) have the advantage." Karimov also spoke around the same time of "mothers who once embarked on communist ideas, but that are now offering their services to Western democracy supporters" without fully understanding potentially problematic consequences (Karimov 2005; 357). These ideas were subsequently echoed by several Uzbek analysts around the same time (Normatov 2006; Nurmatov 2006; Safarov 2006).

Karimov subsequently had little qualms in suggesting that intellectuals, such as Zbigniew Brzezinski, were right in claiming that democracy could not be imported from everywhere (Karimov 2005, 339-340). Cultural distinctiveness extended into the political realm, effectively positioning Uzbekistan outside the Western sphere of influence:

Uzbekistan is in Asia and let everyone remember this. We are members of not only the Organization for Security and Cooperation in Europe, but we are members of Islamic states' organizations as well... We are also Muslims and 85 per cent of our population is Hanafite Muslim... you are forgetting, for example, take Ukraine, it is in Europe, or Georgia, it is also in Europe. Where is Uzbekistan? Look at the map. Is Uzbekistan, the city of Tashkent, not the gate of the East? (quoted in BBC Summary of World Broadcasts 2005)

Whereas, in the mid-1990s SM had been deployed increasingly as a means of denigrating religious extremism and Uzbekistan's domestic opposition, it had now extended to the political and international realms. It legitimated Uzbekistan's increased isolationism from Western governments and political institutions. It also downgraded the extent to which the government was seeking to become a power equivalent to those of Europe and North America. The question, however, is why SM was applied in such a way as to foster anti-Westernism. The explanations for the phenomenon are several, the arguments for which I shall cover before turning to resentment and international misrecognition.

\section{Explanations for the rise of anti-Western SM}

The increased prominence of SM in Uzbekistani political rhetoric is not mono-causal; it was used for a number of reasons and therefore rests on a combination of factors. As already noted, SM fostered national unity, thereby complementing Uzbekistan's project of national self-reliance or national independence (Adams 2010). On top of reinforcing a common identity, SM was also applied by the government and the opposition alike, as Sarah Kendzior $(2014,225)$ persuasively showed, to "make claims about what is acceptably, authentically Uzbek, and, correspondingly, what is immoral, criminal, and not truly Uzbek at all." Not only was this the case in the mid- to late 1990s, as Tashkent sought to placate extremists and opposition parties, but also in the aftermath of the Andijan massacre of May 2005. In the government's most brutal crackdown on protestors, 187 people were killed, according to official sources, ${ }^{5}$ and Nick Megoran $(2008,22-23 ; 2017)$ shows how allusions to "Uzbekness" allowed Karimov to frame the events to his advantage, casting his opponents as aliens.

In like manner, the distinctive anti-Western dent of Karimov's rhetoric also supplied the authorities with a means by which to denigrate opponents, securing the regime from external criticism. Western support for the "Color Revolutions" in the early 2000s and the strong criticism of the Andijan massacre were evidently regarded as threats by the government (llkhamov 2005; D'Anieri 2006; Tucker 2007). 
But those explanations, while relevant, do not explain the full extent of Karimov's sudden shift toward anti-Westernism. Karimov also criticized Russia for its excessive involvement in Ukrainian affairs during the "Color Revolutions" (see BBC Summary of World Broadcasts 2004), but SM never targeted Moscow as such, only the Soviet past.

By way of a counterfactual, Karimov could have continued to criticize the West by invoking technocracy, as he had done before; he could have continued to speak of liberalization as a cause of political-economic instability, an approach that would have remained consistent with Karimov's initial aversion to excessive cultural and ideological rhetoric. To that effect, turning SM into a means of political-cultural exclusion decisively shifted Karimov's rhetoric away from internationalism. More than just placating Western criticism, it helped Uzbekistani authorities shift the priorities of their government in such a way as to secure growing isolationism and to make sense of their inability to guarantee status. Once they could not secure anything resembling equality of treatment, especially from the West, then the temptation was to reinforce the distinctions to which SM had already tacitly alluded. To understand how that is the case it is important to conceptualize the nature of that resentment and just how worthy the Uzbekistani Government considered itself of international recognition. This begs the question, however, of what exactly recognition is and how it is connected to resentment.

\section{Recognition, status, and resentment}

The notions of (mis)recognition and status are often applied by scholars and analysts alike for the sake of contextualizing and understanding the pleas of certain states for international preponderance. Deborah Larson and Alexei Shevchenko (2010,80), for example, claim that by the mid-1990s "Russian elites believed that the West had failed to accord Russia the status and role to which it was entitled, leaving it marginalized and isolated from real decision-making power." The failure to have one's self-image of importance recognized has a number of emotional and discursive ramifications; scholars tend to list anger, resentment, and shame as some of the issues to which misrecognition and loss of status give rise (Heller and Wolf 2014; Tsygankov 2015, 2016). Andrei Tsygankov makes precisely this claim when accounting for Russia's annexation of Crimea:

what made Russia's conflict with Ukraine possible, even inevitable, was the West's lack of recognition for Russia's values and interests in Eurasia, on the one hand, and the critically important role that Ukraine played in the Kremlin's foreign policy calculations, on the other. (Tsygankov 2015, 280).

In a similar vein, Marlene Laruelle $(2009,31)$ suggests that Russian resentment partly explains the rise in nationalism:

the stances taken by Western countries in the Yugoslav wars and the NATO bombing of Serbia in 1999 in response to the Kosovo crisis crystallized the resentment of Russian citizens, who pushed for a pan-Slavic or pan-Orthodox solidarity with Serbia.

Neumann $(1999,2016)$ also shows how certain practices of Western recognition, coupled with internal discourses about whether Russia is Eastern or not, have affected Moscow's foreign policy throughout the ages.

Potential consequences aside, (mis)recognition of status as a concept is difficult to pin down by virtue of its manifold meanings in contemporary international political theory (Bartelson 2013). In many ways, the concept is central to international relations, for states cannot participate in the exclusive club of de jure sovereign states in the absence of recognition, a club that allows actors certain perks, such as being members of the United Nations as well as other global and economic institutions (Wendt 2003; Caspersen 2011; Strömbom 2014). Beyond that thin conception, however, recognition consists of additional meanings, from being respected in international affairs to having specific identities or claims acknowledged (sometimes accepted) by others (Ringmar 2002; Wendt 2003; Lindemann 2010; Wolf 2011; Strömbom 2014). There is nevertheless a fine line between having one's roles accepted and otherwise respected. Whereas, the former requires a positive evaluation of the other's international role, the latter only suggests that consideration ought to be showcased in view of the other's existence within (international) society (Wolf 2011). 
Bearing the distinction in mind, this essay thus sees recognition to be more in line with respecting and supporting the aims of another that are not necessarily deemed contrary to one's vision of the good than simply accepting and unconditionally endorsing another's aims. That said, providing respect can become increasingly difficult in the event of the other being especially adamant about how it ought to be treated, not least should it take grandiose treatment and support for one's initiative as one of its core foreign policy aims. This explains why Russia and its actions are often studied as a case of misrecognition or disrespect of status. Sundry Russian leaders, citizens, and intellectuals considered their country to be a great power (derzhava), entitled to the benefits of complete status recognition: prestige, respect, influence, and visibility (Larson and Shevchenko 2010; Tsygankov 2012). Hence, as others fail to recognize greatness and stature, resentment increases (Tsygankov 2016). This resentment, I argue, prompts, as well as legitimates, discourses centered on exclusion and differentiation-civilizational incompatibilities and incommensurate values-as opposed to internationalism or cosmopolitanism. In this respect, SM allowed Uzbek authorities to exclude those who delayed or refused to provide Uzbekistan with the recognition of status the authorities had sought to achieve. Below I describe that ambition and the sort of grievances that contributed to both growing resentment and exclusionary rhetoric in the early 2000 s.

\section{The status of Uzbekistan}

Allusions to greatness and strategic prominence were often made by Uzbekistan's authorities, not to mention by analysts and foreign observers, all of which reinforced the importance of status in the republic. This line of thinking takes Central Asia to be a key region in international politics, with Uzbekistan harboring an especially important role therein. Discourses relating to geopolitics often did well to reinforce and reproduce this perspective. The concept of the "Eurasian Heartland," for example, found a receptive audience in Uzbekistan's foreign policy community (Megoran 2004; Sharapova 2013), not unlike the remainder of the former Soviet space (Bassin 2016). According to the early twentieth-century British geographer, Halford Mackinder $(1919,186)$, those who could control the "Heartland" of Eurasia, the so-called "World Island," would be close to achieving world domination: "who rules the Heartland commands the World-Island; who rules the World-Island commands the world." Many Uzbekistani analysts echo this thesis. Sevara Sharapova (2003), for example, suggests that the "interests of the major (if not all) players involved in international relations are concentrated in Central Asia," a region which, she argues, will prove crucial to determining key trends in world politics. Likewise, Uzbek political scientist Farkhad Tolipov $(2009,51)$ adapts the Heartland thesis to existing political circumstances, arguing that Central Asia "is a stage on which the new independent states are acting" insofar as they are "pushed by the whim of history and geography into the epicenter of an emerging new world order." Uzbekistan was precisely in that epicenter.

The prominence of geopolitical discourse is compatible with the idea of Uzbekistan being a major Central Asian state. Luca Anceschi (2010) has shown persuasively how domestic and international discourses were intertwined, and how crucial they were to securing the legitimacy of Uzbekistan's Government. In the same way Turkmenistan took neutrality to be central to its external and domestic legitimating strategy, so did Uzbekistan consider status to be a chief aspect of its international role. This idea of grand self-importance has, however, a deeper historical origin. The intellectuals and political activists who cooperated with the Bolsheviks to create Uzbekistan considered the republic to have a significant historical legacy in its own right. Uzbek intellectuals and activists succeeded in carving out Uzbekistan (or the Uzbek SSR) according to their vision of a historically great "Bukhara," creating an entity that combined "all of Central Asia's population and almost all of its historical cities" (Khalid 2016, 276). That sense of importance was also translated into Soviet policy. Tashkent acquired important status within the Union, hosting numerous events and international conferences (Nichol 1995, 17). The Uzbek SSR was also the third most (indirectly) represented Union republic of the Soviet Union delegation at the United Nations General Assembly between 1950 and 1991, behind only the RSFSR and Lithuanian SSR (Nichol 1995, 14-15). ${ }^{6}$ Were that not enough, Soviet officials recognized the republic's capacity 
for regional hegemony (Carlisle 1995), and Moscow continued to do so after the collapse of the USSR, insofar as it balanced against Uzbekistani influence in Central Asia (Allison 2004). Outside the former Soviet space, however, analysts have also alluded to Uzbekistan's potential hegemonic status within Central Asia (Critchlow 1990, 1991; Hyman 1993; Cornell 2000; Deyermond 2009; Spechler and Spechler 2009; Megoran 2017).

In light of perceived Uzbekistani historical self-importance, it is not surprising to witness Karimov (1992a) speaking optimistically of the country's great past, special position, and economic wealth in the wake of independence, a claim he often summarized with recourse to the slogan a "future great state (kelajagi buyuk davlat)." Even in a speech made celebrating Uzbekistan's 25-year independence anniversary, Karimov spoke again of Uzbekistan's greatness lying close on the horizon:

It was in those very times, when our people, by demonstrating in practice their resoluteness and steadfastness, did not lose their belief in the bright and great future of our Uzbekistan and Insha'Allah will never ever lose it. $(\text { Karimov 2016) })^{7}$

References to SM also bolstered the alleged historical importance of the country. Speaking of the morals professed by the country's ancestors, most especially Amir Timur (otherwise known as Tamerlane in the West), allowed Karimov to "establish a continuity in leadership of Uzbekistan that began in the time of Timur and continued to the present day" (Adams 2010, 147).

\section{Uzbekistan's equality of status}

Allusions to the strategic preponderance of Central Asia and the great future of the state were compatible with the notion of Uzbekistan having, if not deserving, equality of status in the international arena (Teles Fazendeiro 2017a, 2017b). It is a conception rooted in Soviet thinking, particularly in the ideas of sovereignty and distributive justice, both of which gained special prominence over the course of the USSR's nationalities debates in the 1980s (Bahry and Nechemias 1981; Walker 2003). Historical origins aside, Karimov and local authorities routinely alluded to the importance of ensuring equality in Uzbekistan's relations. ${ }^{8}$ As early as 1991, when Russia and Uzbekistan consolidated their first bilateral relations, the governmental press labeled the meeting as an encounter of "equals" (Fenyutin 1991). Guaranteeing equality of status was meant to ensure the republic would not obtain less prestige or fewer (political and economic) advantages than those from whom it extracted concessions. The aim was even institutionalized in Uzbekistan's 1996 Foreign Policy law, which took equality to be the foundation of international interaction.

The Republic of Uzbekistan builds mutually advantageous relations with all states on equal terms, relations which rule out any possibility of interference in its internal affairs or of limitations on its independence and sovereignty, and of interstate relations being driven by ideology alone. (Lex.uz 1996; italics added)

In addition to legal stipulations, Karimov spoke repeatedly of equality in international politics. Upon achieving independence, he argued that relations within the Commonwealth of Independent States (CIS), particularly with Russia, were to be developed on the condition of equality (Karimov 1992b).

The West was no exception. Karimov was keen on securing Western investment and recognition, though on the basis of equality: "there are new opportunities at hand arising under present-day conditions for equitable relations with the United States, Germany, Spain, France, Italy and other developed countries" (Karimov 1992b, 32; emphasis added).

All in all, the self-image of Uzbekistani authorities and intellectuals regarding the country's importance laid down an ambitious set of demands. Not only was the government's role predicated on fostering spiritual-moral revival in conjunction with economic growth through a model of gradual authoritarian reform, it was also meant to ensure equality of status in the international arena. In other words, Uzbekistani authorities mentioned the need for being respected as an important equal partner, which meant they were keen on securing visibility alongside important states as well as on securing economic investment. As this promise failed to come to fruition, Uzbek authorities showcased their 
resentment and qualified that ambition in the 2000s; complete equality was simply not feasible in view of intractable cultural differences. Below I show the events that sparked growing resentment.

\section{Growing grievances against the West}

Grievances against Western misrecognition or perceived disrespect grew gradually throughout the 1990s and early 2000s. Karimov, as already noted, built on SM in order to highlight the alleged distinctiveness of Uzbek "Eastern" culture. None of these rhetorical cues, however, were meant to antagonize Uzbekistan's relationship with the so-called "West," though it did help distinguish Uzbekistan, culturally at least, from that part of the world. In this regard, the West too, not least the United States, reinforced Uzbekistani “Easternness." Undecided about the best way in which to interact with Central Asian states, NATO and several Western experts debated the likelihood of Uzbekistan and its neighbors following a Turkish or Iranian route of political development - that is, whether they would embrace secularism as opposed to Islamic fundamentalism (Friedman 1992; Hiro 1994; Usmanov 1994). Building the distinction along those lines presupposed that Uzbekistan and its neighbors were not necessarily related to the former Soviet states of Eastern Europe, none of which had their transition models cast in those terms. Central Asian states were rather a group of their own. Karimov was thus compelled in the early 1990s to signal just how far he was seeking to distance himself from the "Iranian" model, and to embrace technocratic, secular development of the like extolled by Western states (Teles Fazendeiro 2017b; Chapter 6). Besides alternative depictions of development, NATO initially saw Turkey as Central Asia's "natural" ally (Winrow 2001), a state that has also struggled to define the extent of its belonging to the West (Neumann 1999, 39-64).

Were that not enough, the cultural rift that justified Uzbekistani distinctiveness was only reinforced by administrative categorizations taken by the "Western allies." The US Government, for example, considered Central Asia in the late 1990s as belonging to Central Command (CENTCOM), which also encompassed the Middle East (Blank 2001). Later, after the 2005 Andijan Massacre, the US State Department came to view Central Asia as part of its South Asian division rather than of its European affairs (Heathershaw 2007).

At any rate, labeling and uncertainty over how to conceive of Central Asia in general and Uzbekistan in particular in no way implied growing resentment or enmity, though it certainly provided a base for growing distinctiveness and for reinforcing Uzbekistani SM. None of those initiatives were intent on fostering —nor did they result in—antagonism. Instead, resentment spurred from Karimov's inability to secure the sort of respect for Uzbekistani equality of status that he had initially envisaged. It is only when the already distinct West failed to accede to those recognition demands that resentment arose by way of an increasingly exclusionary SM rhetoric.

\section{The basis for resentment}

Karimov had sought recognition of status, both as an economic heavyweight and as a strategic actor, yet neither of which was realized as planned. With the exception of Germany and Russia, most of the investment received by Uzbekistan throughout the 1990s originated from Asia, especially from South Korea and Japan, with China increasing its stake in Uzbekistan's balance of trade. ${ }^{9}$ In any event, Karimov had cast Uzbekistan as a country rich in natural resources, a potential investment platform for Western businesses. Upon visiting the United States in 1996, he gave a lengthy interview to NBC, detailing the country's investment potential and how his technocratic approach guaranteed political-economic stability (NBC 1996). He also met with several American business representatives with the expectation of obtaining American financial support. While several companies voiced interest, many of the deals were not implemented. Enron, for example, had voiced a keen interest in investing in the country, but the deal backfired in the late 1990s, mainly because of Russian pressure, but also due to Uzbekistan's increasingly autarkic policies (Paige 1998). 
The prospects of greater economic cooperation aside, it was mainly the political atmosphere that compromised the sort of equality of status for which Karimov had strived. Though not as economically influential as initially propounded, Uzbekistan could in theory have become an important political and strategic partner for the West. That did not, however, prove to be the case, as several Western governments were reluctant to interact fully with the republic. This was especially the case of the United States. When the George H.W. Bush administration first set out its recognition policy for the newly independent states of the USSR in December 1991, Uzbekistan was to have its diplomatic acknowledgement delayed in light of its human rights'violations (Rich 1993). Although the United States did eventually change tack by formalizing diplomatic relations with Uzbekistan in early 1992, the promise of a fruitful relationship, based on "equitable" bilateral relations, was hardly on Washington's agenda. Former Secretary of State James Baker accounts for the initial tensions between the two governments during his visit to Tashkent in 1992. He refers to how Karimov protested against the visibility which Kazakhstan-Uzbekistan's neighbor-was obtaining in the wake of the USSR's collapse, as if his government were also entitled to equal recognition. But Karimov's private complaints led nowhere in particular, with Baker underscoring that political reform had to come first (Baker 1995, 632).

As their relationship progressed, tensions persisted. Uzbekistan had barely obtained the same type of recognition as its neighbors, namely Kazakhstan and Kyrgyzstan, the leaders of which were invited to the White House in the early 1990s_long before Karimov's official visit in 1996. Even during VicePresident Al Gore's travels in the region in the early 1990s, Uzbekistan was conspicuously ignored. In fact, considerable lobbying efforts were necessary for the US Government to allow Karimov to travel to the United States and visit the White House (Kangas 1996).

The visit aside, it was not so much the fact that Uzbekistan was recognized as a crucial economic and political actor that explained the American concession, but that Washington began taking seriously the security situation in Central Asia. The US Government officials, particularly from the Department of Defense, understood that some interaction with the region-Uzbekistan in particular-was necessary in view of the ongoing conflict in Afghanistan and Tajikistan. This in turn led to a much broader debate within the American establishment on whether human rights trumped security, a debate that persisted beyond the 1990s. ${ }^{10}$ Hence, it was mainly the stabilizing role of Uzbekistan that was rewarded by American authorities, not its status in the region. American authorities continued to have few qualms in persisting with their-often public-criticism of the government, as was the case during Secretary of State Madeleine Albright's visit to the country in 1999. The visit was overshadowed by a previous attempt on Karimov's life, leading local authorities to increase the level of repression (Polat and Butkevich 2000). This increased suppression was heavily criticized by Albright (Department of State 2000), ${ }^{11}$ with Karimov in turn having already shown his resentment against American lecturing:

I asked her a question: I asked her who best knew the state of affairs in the USA. In astonishment, she said that the Americans did. Who, I asked, best knows the state of affairs in Uzbekistan? Of course, we ourselves do. (quoted in BBC Worldwide Monitoring 1999)

At that point, however, the justifications against external criticism rested on Karimov's technocratic expertise, not on the alleged civilizational and moral differences between the two cultures. It would take further misrecognition in order to shift Karimov's rhetoric toward SM and especially toward an anti-Western variant of SM, as discussed above. That said, the situation could potentially have improved at the beginning of the so-called "War on Terror" in late 2001, that is, with the start of the US campaign in Afghanistan. Despite Uzbekistan's negative image in the West, particularly within the United States, the country's location and stability meant it provided important security guarantees for US war efforts. Karimov took the opportunity to build on the burgeoning security relationship, campaigning for greater financial and political support, which was to be fully recognized by way of a written partnership agreement, namely the "Declaration on the Strategic Partnership and Cooperation Framework between the United States of America and the Republic of Uzbekistan" (Department of State 2002). Partly for the sake of obtaining a base in Karshi-Khanabad, Washington acquiesced, though the formal agreement had little impact, since sundry American officials continued to criticize the government and its human rights 
practices (Heathershaw 2007; Cooley 2008). It did not guarantee any semblance of equality. Secretary of State Colin Powell even refused at one point to acknowledge advances in Uzbekistani reforms, which, on top of being a very public reprimand, also meant suspending American financial aid (Daly et al. 2006).

As the political differences increased, the "Color Revolutions" only enhanced Uzbekistani resentment, thereby dispelling the promise of an equal partnership. Indeed, Uzbek authorities began restricting the actions of Western-sponsored organizations, such as the Open Society Institute (llkhamov 2005). The situation then escalated when Uzbekistani stability ceased to be as publicly supported by the US Government. When Uzbekistan was subject to a terrorist attack near the American and Israeli embassies in spring 2004, not to mention to a potential insurgency near the Chorvak reservoir, the US Government offered little public support. ${ }^{12}$ With the alleged partnership deteriorating, Karimov wrote to his American counterpart in order to request support and political recognition. President Bush did not, however, abide by Karimov's plea, instead demanding further economic and political reforms (Daly et al. 2006). All such actions only reinforced Uzbekistani officials' growing resentment, as pointedly summarized by Martha Brill Olcott (2007) in a testimony to the House of Representatives:

For their part the Uzbeks were bitterly disappointed. They had thought that they were getting a strategic friendship with the US akin to what had been on offer in earlier decades, and that the US would support the full-blown reform of the country's security establishment, as well as provide massive economic and political assistance.

It was not just the United States, however, that contributed to growing resentment. Other Western actors had also done little to reinforce Uzbekistan's initial, albeit very vague, commitment to developing "Western" institutions, such as democracy and a market economy. Though the EU, for instance, developed partnership agreements with the Central Asian republics, its interest in the region remained low, with its much-publicized transport and network projects, for example, barely being implemented (Laruelle 2015).

The EU was not alone in this regard. The penchant for diversifying the logistical and transport routes of the Central Asian states failed in the 1990s and also did little to reinforce the strategic importance of the region. Karimov had, for instance, joined American Senator Sam Brownback's Silk Road Strategy, designed to develop alternative energy and transport routes for Central Asian and Caucasus states, but the program failed to pass through Congress (Govtrack.us 2006). Even Germany, by far Uzbekistan's most important Western economic partner in the 1990s, began taking issue with the republic. Covering Gerhard Schroeder's visit to Uzbekistan in 2001, the press alluded to the problematic political and economic situation in the country (Prause 2001). On top of increasingly tense interactions with certain states, resentment was also visible in Uzbekistan's relations with Western-sponsored organizations. To take an example, during a summit set up by the European Bank for Reconstruction and Development in May 2003, Karimov displayed his frustration with the officials who actively criticized the government's model of economic growth by removing his translating gear on live television (Lewis 2008, 35).

All in all, once the Andijan Massacre occurred in May 2005, it is hardly surprising that Uzbek authorities had little if any prospects of obtaining "Western" support. The event only reinforced the differences to which Karimov had increasingly alluded. Uzbekistan was at the time increasingly isolated from the US Government, not least because of the public rebukes made by its representatives. In fact, three American senators travelled to the country in order to pressure the government, though Uzbekistan's President refused to receive them, forcing them to criticize the regime at the US Embassy (see US Embassy 2005). Hence, by 2005 grievances were at an all-time high. A rhetoric of anti-Western SM allowed Karimov not only to downplay external criticism, but also to account for the persistent lack of international recognition. Internationalism was downplayed, which in turn legitimated Uzbekistan's increased political and economic isolationism from the West.

\section{Conclusion}

The rise of exclusionary SM in Uzbekistani politics, particularly its anti-Western variant, followed a period of increased tribulation. Discourse had not initially been exclusionary, but gradually became 
so. Though SM was a useful means by which to downplay criticism, it was also a consequence of increased resentment, of Uzbekistan not obtaining the level of international recognition that Karimov had sought to achieve. In the end, however, the preponderance of SM proved short lived. It did not remain a core priority of the government, particularly at the international level. This happened for several reasons. For one, Karimov certainly felt more comfortable in underscoring the technocratic credentials of his government, which was how he had actually built his public repertoire in the late 1980s and early 1990s. The international context, by virtue of the 2008 financial crisis, also offered Karimov the opportunity to remain an outspoken supporter of Uzbekistani-styled (authoritarian) technocracy. Karimov (2009) subsequently published a book online, quickly translated into English, in which he extolled the usual arguments about the benefits of state-regulated management. Besides technocracy, NATO members and the United States in particular still considered Uzbekistan to be an important partner in the so-called "War on Terror." As relations with Pakistan-a major transit country for the US war effort-deteriorated in 2011, Uzbekistan gained strategic leverage due to its geographical position and stable security situation. It eventually managed to become an important partner for the Northern Distribution Network, a complex logistical route aimed at both evacuating and delivering NATO supplies to Afghanistan.

All in all, neither Karimov nor the "Western" partners with whom he interacted were interested in foreclosing the possibility of rapprochement. The government ceased very public criticisms of "Western" morality and practices, at least on the international front, which is not to say that the discourse has not had lasting effects. This is where the growing prominence of anti-Western SM proved important. In spite of a stronger security relationship with both the US Government and NATO in general after 2008, Karimov was no longer open to any political, especially public, setbacks. Deeper political engagement was pre-emptively foreclosed, as several of the organizations that once operated in the country remained unable to work. The OSCE center in Tashkent, for example, which was downgraded to Project Coordinator status in summer 2006, continued to have its operations heavily restricted.

The situation has shifted with the rise of Shavkat Mirziyoyev to Uzbekistan's presidency. Both in his first speech to Parliament in September 2016, still as Prime Minister, and subsequently in the strategic document he adopted for the country in the beginning of 2017, Uzbekistan's new president has underscored a pragmatic - equally technocratic - approach, keen on securing international investment, rapprochement with neighbors, and improving the image of the country abroad (Mirzyoyev, 2016; Development Strategy 2017). Mirziyoyev has thus the unique opportunity to break away from the increased isolationism invoked by Karimov since the early 2000s. He has spoken less of greatness, showing instead greater sensitivity to "soft power" and image-making than Karimov (Podrobno.uz 2017).

Apart from the more positive developments of Mirziyoyev's first year in office, not least in what seems to be a substantial decrease in the National Security Services' role in the local political economy, much is yet to be said on the extent to which they mark a radical break from the Karimov era. Despite growing media freedoms, many of the symbols and discursive ploys applied during the Karimov era still abound. Whereas, in early 2013, for example, Uzbek authorities took to admonishing the use of tattoos as being a perceptively "un-Uzbek" practice (RFE/RL 2013), officials under the "new" Mirziyoyev era have similarly appealed for Uzbek singers not to showcase body art in their videos (RFE/RL 2018). SM, though not necessarily its anti-Western variant, remains pervasive within Uzbekistani domestic politics. A complete rupture with the past was perhaps unrealistic, not least because former President Karimov continues to be lauded by his successor, and nothing is to suggest that anti-Western SM will cease to be invoked. In the event of the pragmatic discourses falling on deaf ears or else failing to translate into improved economic performance, much like they did under Karimov, exclusionary SM can again regain prominence at the international level. Mirziyoyev has to guarantee some level of success to that effect and foreign interlocutors, principally from the West, need to tread carefully in how they recognize (or not) those policies. 


\section{Notes}

1. Beyond the relationship to the East, however, Karimov also took Uzbekistan's SM to be a product of the Silk Road, which "linked the heart of Asia with the Middle East, Europe and Africa" (Karimov 1992b, 58-59).

2. Some of these events have been reported over the years, such as the government criticizing the way Uzbek pop stars present themselves in Uzbek videos. See reports in Eurasianet $(2016,2017)$.

3. See some of the cultural demands made by Birlik, particularly with regard to language in the 1989 "Charter of the Birlik's People Movement" (Charter 1992).

4. See "Constitution of Uzbekistan," http://www.ksu.uz/en/page/index/id/7; accessed 1 September 2016.

5. For reports on the massacre, see Akiner (2005), ICG (2005), and HRW (2006).

6. The Soviet Union pushed for a system of indirect representation at its UN General Assembly delegation. The Uzbek SSR was represented eight times during the period. However, neither Ukraine nor Belarus figured in that system of indirect representation for the reason that they were already directly represented at the UN General Assembly.

7. The speech written before Karimov's death was made available in the end of August. Karimov was already gravely ill on September 1st, Independence Day, and would then die the next day.

8. See Teles Fazendeiro (2017a, 2017b) for a detailed discussion of the origins of Uzbekistani pleas for equality of status.

9. For data on Uzbekistan's main trade partners over the years, see Asian Development Bank (2010). For trade data in more recent years, see Asian Development Bank (2017).

10. For some references to these debates and whether and how the United States should be involved in Central Asia, see Talbott (1997) and Brzezinski (1997).

11. For details regarding the attempt on Karimov's life, see Polat and Butkevich (2000).

12. On these events and the reactions to which they gave rise, see Eurasianet (2004a, 2004b).

\section{Acknowledgements}

The author is grateful to Alina Jasina and Masatomo Torikai for comments, and to Naomi Teles Fazendeiro for helpful editing. Fundação de Ciência e Tecnologia, a Portuguese scholarship foundation, has also been crucial in supporting my postdoctoral research at the Centre for Social Studies at the University of Coimbra.

\section{Disclosure statement}

No potential conflict of interest was reported by the author.

\section{Funding}

This work was supported by the Fundação de Ciência e Tecnologia [grant number 5332].

\section{References}

Abdullayev, M., M. Abdullayeva, F. Abdullayeva, G. Abdurazzoqova, Q. Abdurasulova, F. Abdurahmonov, S. H. Abduqosimov, et al. 2009. Mustaqillik: Izohli Ilmiy-Ommabop Lug'at [Self-Reliance: Popular-Scientific Glossary]. Tashkent: Sharq.

Adams, L. 2008. “Can We Apply Post-Colonial Theory in Central Asia?" Central Eurasian Studies Review 7 (1): 2-7.

Adams, L. 2010. The Spectacular State: Cultural and National Identity in Uzbekistan. London: Duke University Press.

Allison, R. 2004. "Strategic Reassertion in Russia"S Central Asia Policy." International Affairs 80 (2): 277-293.

Allworth, A. E. 1990. The Modern Uzbeks from the Fourteenth Century to the Present: A Cultural History. Stanford, CA: Hoover Institution Press.

Akiner, S. 2003. Violence in Andijan, 13 May 2005: An Independent Assessment. Washington, DC: John Hopkins University, Central Asia-Caucasus Institute \& Silk Road Studies Program.

Anceschi, L. 2010. "Integrating Domestic Politics and Foreign Policy Making: The Cases of Turkmenistan and Uzbekistan." Central Asian Survey 29 (2): 143-158.

Asian Development Bank. 2010. “Uzbekistan: Key Indicators for Asia and the Pacific 2010," August. http://www.adb.org/ publications/key-indicators-asia-and-pacific-2010.

Asian Development Bank. 2017. “Uzbekistan: Key Indicators for Asia and the Pacific 2017," September. https://www.adb. org/publications/key-indicators-asia-and-pacific-2017.

Bahry, D., and C. Nechemias. 1981. "Half Full or Half Empty? The Debate over Soviet Regional Equality." Slavic Review 40 (03): 366-383.

Baker, J. 1995. The Politics of Diplomacy: Revolution, War and Peace, 1989-1992. New York, NY: G.P. Putnam's Sons.

Baranovsky, V. 2000. "Russia: A Part of Europe or apart from Europe?" International Affairs 76 (3): 445-458.

Bartelson, J. 2013. "Three Concepts of Recognition." International Theory 5 (01): 107-129. 
Bassin, M. 2016. The Gumilev Mystique: Biopolitics, Eurasianism, and the Construction of Community in Modern Russia. London: Cornell University Press.

BBC Monitoring International Reports. 2005. "New Uzbek Parliament Part of Democratic Nation-Building—President," January 29. Accessed December 2012. Nexis.com.

BBC Summary of World Broadcasts. 1993a. “Uzbek President Tells 'Pravda' He is Looking for Cooperation, Not Aid," August 7. Accessed April 2012. Nexis.com.

BBC Summary of World Broadcasts. 1993b. “Uzbekistan; Karimov Defends His Policies against Accusations of Strong-Arm Tactics," June 12. Accessed March 2012. Nexis.com.

BBC Summary of World Broadcasts. 2004. “Uzbek Leader's Interview in Parliament Intermission," December 3. Accessed March 2012. Nexis.com.

BBC Summary of World Broadcasts. 2005. “Uzbek Leader Says No International Probe into the Andijan Crisis—Fuller," May 25. Accessed March 2012. Nexis.com.

BBC Worldwide Monitoring. 1999. "Refile Uzbek Head: 'We Have to Think about NATO Membership'—Full Version," May 1. Accessed March 2012. Nexis.com.

Blank, S. 2001. "The United States in Central Asia." In Central Asian Security: The New International Context, edited by Roy Allison and Lena Jonson, 127-151. London: Brookings Institution Press.

Brzezinski, Z. 1997. The Grand Chessboard: American Primacy and Its Geostrategic Imperatives. New York, NY: Basic Books.

Carlisle, D. 1995. "Geopolitics and Ethnic Problems of Uzbekistan and Its Neighbours." In Muslim Eurasia: Conflicting Legacies, edited by Y. Ro'i, 71-104. London: Frank Cass.

Caspersen, N. 2011. Unrecognized States: The Struggle for Sovereignty in the Modern International System. Cambridge: Polity.

Charter. 1992. "Charter of the Birlik People's Movement [1989]." In Perestroika in the Soviet Republics: Documents on the National Question, edited by C. Furtado Jr and A. Chandler, 354-355. Oxford: Westview Press.

Cooley, A. 2008. “U.S. Bases and Democratization in Central Asia." Orbis 52 (1): 56-90.

Cornell, S. E. 2000. “Uzbekistan: A Regional Player in Eurasian Geopolitics?” European Security 9 (2): 115-140.

Critchlow, J. 1990. "Will Soviet Central Asia Become Greater Uzbekistan?" Report on the USSR 2 (37): 17-20.

Critchlow, J. 1991. Nationalism in Uzbekistan: A Soviet Republic's Road to Sovereignty. London: Westview Press.

Daly, J., K. H. Meppen, V. Socor, and S. F. Starr. 2006. "Anatomy of a Crisis: U.S. - Uzbekistan Relations, 2001-2005." Central Asia-Caucasus Institute \& Silk Road Studies Program. Accessed August 2009. http://www.silkroadstudies.org/new/inside/ publications/0602Uzbek.pdf

D'Anieri, P. 2006. "Explaining the Success and Failure of Post-Communist Revolutions." Communist and Post-Communist Studies 39 (3): 331-350.

Department of State. 2000. "Secretary of State Madeleine K. Albright and Uzbekistan Foreign Minister Abdulaziz Kamilov," April 18. http://1997-2001.state.gov/www/statements/2000/000418b.html.

Department of State. 2002. "Declaration on the Strategic Partnership and Cooperation Framework between the U.S. of America and the Republic of Uzbekistan," July 8. https://2001-2009.state.gov/p/eur/rls/or/2002/11711.htm.

Development Strategy. 2017. “On Uzbekistan's Development Strategy," February 8. http://tashkenttimes.uz/national/541uzbekistan-s-development-strategy-for-2017-2021-has-been-adopted-following-discussion.

Deyermond, Ruth. 2009. "Matrioshka Hegemony? Multi-Levelled Hegemonic Competition and Security in Post-Soviet Central Asia." Review of International Studies 35 (1): 151-173.

Eurasianet. 2004a. "Fighting Rages for Third Straight Day in Uzbekistan." March 29. http://www.eurasianet.org/departments/ insight/articles/eav033004.shtml.

Eurasianet. 2004b. "Suicide Bombers Hit Uzbek Capital, Leaving at Least Five Dead." July 29. http://www.eurasianet.org/ departments/insight/articles/eav073004.shtml.

Eurasianet. 2016. “Uzbekistan: Pop Stars under Scrutiny for Producing Immoral, Unpatriotic Material." June 16. http://www. eurasianet.org/node/79276.

Eurasianet. 2017. “Uzbekistan: Artists Need Permission to Post on YouTube." June 26. http://www.eurasianet.org/node/84121.

Fenyutin, S. 1991. "Uzbekistan I Rossiya-Dialog Ravnopravnykh [Uzbekistan and Russia—Dialogue of Equals]." Pravda Vostoka, October 29.

Friedman, T. 1992. “U.S. to Counter Iran in Central Asia." The New York Times, February 6. http://www.nytimes.com/1992/02/06/ world/us-to-counter-iran-in-central-asia.html.

Govtrack.us. 2006. "Silk Road Strategy Act of 2006." Accessed November 24, 2016. https://www.govtrack.us/congress/ bills/109/s2749

Heathershaw, J. 2007. "Worlds Apart: The Making and Remaking of Geopolitical Space in the US-Uzbekistani Strategic Partnership." Central Asian Survey 26 (1): 123-140.

Heathershaw, J. 2010. "Central Asian Statehood in Post-Colonial Perspective." In Stable outside, Fragile inside? Post-Soviet Statehood in Central Asia, edited by Emilian Kavalski, 87-106. London: Routledge.

Heller, R., T. Forsberg, and R. Wolf, eds. 2014. "Status and Emotions in Russian Foreign Policy." Communist and Post-Communist Studies 47 (3-4; special issue).

Hiro, D. 1994. Between Marx and Muhammad: The Changing Face of Central Asia. London: Harper.

Hirsch, F. 2000. "Toward an Empire of Nations: Border-Making and the Formation of Soviet National Identities." Russian Review 59 (2): 201-226. 
HRW (Human Rights Watch). 2006. “Events of 2005." Accessed May 2010. http://www.hrw.org/world-report-2006/uzbekistan Hyman, A. 1993. "Moving out of Moscow's Orbit: The Outlook for Central Asia." International Affairs 69 (2): 289-304.

ICG (International Crisis Group). 2005. "Uzbekistan:The Andijon Uprising," May 25. http://www.crisisgroup.org/en/regions/ asia/central-asia/uzbekistan/B038-uzbekistan-the-andijonuprising

Ilkhamov, A. 2005. "The Thorny Path of Civil Society in Uzbekistan." Central Asian Survey 24 (3): 297-317.

Kangas, R. 1996. "High Expectations: Karimov's Visit to the United States." OMRI Analytical Brief, June 21. http://fa.osaarchivum. org/ft?col=210\&i=193

Karimov, I. 1992a. "O'zbekiston-Kelajak Buyuk Davlat [Uzbekistan-A Future Great State]." In O'zbekiston: Milliy Istiqlol, Iqtisod, Siyosat, Mafkura [Uzbekistan: National Independence, Economy, Politics, and Ideology], Vol. 1 (1996), 95-130. Tashkent: O'zbekiston.

Karimov, I. 1992b. Uzbekistan — The Road of Independence and Progress. Tashkent: Uzbekiston.

Karimov, I. 1993a. "Vatan, El Manfaati-Muqaddasdir [the Homeland and the People's Interest Are Sacred]." In Vatan Sajdagoh Kabi Muqaddasdir [The Homeland Is Sacred Like the Altar], Vol. 2 (1996), 61-73. Tashkent: O'zbekiston.

Karimov, I. 1993b. "Vatanimizning Salohiyati Va Obro'yuni Yanada Oshiraylik [Increasing Again the Power and Esteem of Our Homeland]." In Vatan Sajdagoh Kabi Muqaddasdir [The Homeland Is Sacred Like the Altar], Vol. 2 (1996), $131-147$. Tashkent: O'zbekiston.

Karimov, I. 1998. Uzbekistan on the Threshold of the Twenty-First Century. New York, NY: St. Martin's Press.

Karimov I. 2005. "Bizni Tanlagan Yo'limizdan, Hech Kim Qaytarolmaydi [No One Will Divert Us from Our Chosen Path]." In O'zbek Xalqi Hech Qachon, Hech Kimga Qaram Bo'Imaidi [The Uzbek People Will Never be Dependent on Anyone], May 14, Vol. 13, 306-368. Tashkent: O'zbekiston.

Karimov, I. 2008. Yuksak Ma'naviyat_Yengilmas Kuch [High Spirituality-Morality: An Invincible Force]. Tashkent: Ma'naviyat.

Karimov, I. 2009. The Global Financial-Economic Crisis. Accessed June: Ways and Measures to Overcome It in the Conditions of Uzbekistan. http://mfa.uz/eng/press_and_media_service/dates/110309_book/.

Karimov, I. 2016. "Festive Congratulation by the President of Uzbekistan," August 31. http://www.mfa.uz/en/press/ news/2016/08/8219/.

Kendzior, S. 2014. "Reclaiming Ma'naviyat: Morality, Criminality, and Dissent Politics in Uzbekistan." In Ethnographies of the State in Central Asia: Performing Politics, edited by Madeleine Reeves, Johan Rasanayagam and Judith Beyer, $223-242$. Bloomington: Indiana University Press.

Khalid, A. 2016. Making Uzbekistan: Nation, Empire, and Revolution in the Early USSR. London: Cornell University Press.

Kudaibergenova, D. 2016. "The Use and Abuse of Postcolonial Discourses in Post-Independent Kazakhstan." Europe-Asia Studies 68 (5): 917-935.

Larson, D., and A. Shevchenko. 2010. "Status Seekers: Chinese and Russian Responses to U.S. Primacy." International Security 34 (4): 63-95.

Laruelle, M. 2009. In the Name of the Nation: Nationalism and Politics in Contemporary Russia. New York, NY: Palgrave Macmillan.

Laruelle, M. 2010. "The Ideological Shift on the Russian Radical Right: From Demonizing the West to Fear of Migrants." Problems of Post-Communism 57 (6): 19-31.

Laruelle, M. 2015. “The US Silk Road: Geopolitical Imaginary or the Repackaging of Strategic Interests?." Eurasian Geography and Economics 56 (4): 360-375.

Lewis, D. 2008. The Temptations of Tyranny in Central Asia. New York, NY: Columbia University Press.

Lex.uz. 1994. "Respublika 'Ma'naviyat Va Ma'rifat' Jamoatchilik Markazining Faoliyatini Tashkil Etish To'g'risida [on the Organization of the Republican Centre for Spirituality and Enlightenment]." Accessed May 2016. lex.uz/pages/getpage. aspx?lact_id=196309\&query=Маънавият\%20ва\%20Маърифат\%20Маркази

Lex.uz. 1996. "Ob Osnovnykh Printsipakh Vneshnepoliticheskoi Deyatel'nosti Respubliki Uzbekistan [on the Main Principles of Uzbekistan's Foreign Relations]." December 26. http://lex.uz/pages/getpage.aspx?lact_id=39322\&query=

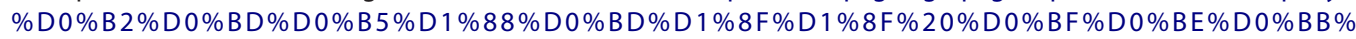
D0\%B8\%D1\%82\%D0\%B8\%D0\%BA\%D0\%B0

Lindemann, T. 2010. Causes of War: The Struggle for Recognition. Colchester: ECPR.

Mackinder, H. J. 1919. Democratic Ideals and Reality: A Study in the Politics of Reconstruction. New York, NY: Henry Holt And Company.

March, A. 2003. "From Leninism to Karimovism: Hegemony, Ideology, and Authoritarian Legitimation." Post-Soviet Affairs 19 (4): 307-336.

Martin, T. 2001. "An Affirmative Action Empire: The Soviet Union as the Highest Form of Imperialism." In A State of Nations: Empire and Nation-Building in the Age of Lenin and Stalin, edited by T. Martin and R. G. Suny, 67-90. Oxford: Oxford University Press.

Markowitz, L. 2009. "How Master Frames Mislead: The Division and Eclipse of Nationalist Movements in Uzbekistan and Tajikistan." Ethnic and Racial Studies 32 (4): 716-738.

Megoran, N. 2004. "Revisiting the 'pivot': The Influence of Halford Mackinder on Analysis of Uzbekistan's International Relations." The Geographical Journal 170 (4): 347-358.

Megoran, N. 2008. "Framing Andijon, Narrating the Nation: Islam Karimov's Account of the Events of 13 May 2005. . Central Asian Survey 27 (1): 15-31. 
Megoran, N. 2017. Nationalism in Central Asia: A Biography of the Uzbekistan-Kyrgyzstan Boundary. Pittsburgh, PA: University of Pittsburgh Press.

Mirzyoyev, S. 2016. “Vystuplenie Prem'er-Ministra Na Zasedanii Palat Parlamenta [Address of the Prime Minister at a Session of the Houses of Parliament]." Gazeta.Uz., September 9. https://www.gazeta.uz/2016/09/09/speech/

NBC. 1996. “Uzbekistan President Islam Karimov and OPIC President Ruth Harkin Discuss a Joint U.S.-Uzbekistan Energy Venture." June 24. Accessed October 2011. Nexis.com.

Neumann, I. 1999. The Uses of the Other: The "East" in European Identity Formation. Minneapolis, MN: University of Minnesota Press.

Neumann, I. 2016. Russia and the Idea of Europe: A Study of Identity and International Relations. London: Routledge.

Nichol, J. 1995. Diplomacy in the Former Soviet Republics. London: Praeger.

Normatov, I. 2006. "Kimdan Erkinmiz? [Our Freedom from Whom?]." Hurriyat. Accessed May 2012. http://n.ziyouz.com/ matbuotuz/hozirgi-davr-matbuoti/ibrohim-normatov-kimdan-erkinmiz-2006

Nurmatov, A. 2006. "Internet Globallshuv [Globalized Internet]." Hurriyat. Accessed September 2015. http://www.ziyouz. com/index.php?option=com_content\&task=view\&id=8251.

Olcott, M.B. 2007. "U.S. Relations to Uzbekistan: A Double Standard or Second Class Treatment?" Carnegie Endowment for Peace, June 14. http://www.carnegieendowment.org/files/olcottcompleteltestimony__2_.pdf

Paige, M. 1998. "A Little Sizzle in the Region's Expectations." Petroleum Economics, September 22. Accessed August 2012. Nexis.com.

Podrobno.uz. 2017. "Myagkaya Sila [Soft Power]." Podrobno.Uz. Accessed June 27. http://podrobno.uz/cat/politic/ myagkayasilaimidzhidinamichnostkakimstanovitsyauzbekistaniegovneshnyayapolitika/

Polat, A., and N. Butkevich. 2000. "Unravelling the Mystery of the Tashkent Bombings: Theories and Implications." Demokratsiya 8 (4): 541-553.

Prause, J. 2001. “Usbekistans Devisenpolitik Stört Auslandsinvestoren [Uzbekistan's Exchange Rate Policy Bothers Foreign Investors]." Financial times Deutschland, April 5. Accessed November 2012. Nexis.com.

Rashidov, S. 1978. Soviet Uzbekistan. Moscow: Progress.

RFE/RL. 2013. “Uzbek State TV Warning: Tattoos Cause Moral Damage," February 21. https://www.rferl.org/a/uzbekistantattoos-tv-warning/24908973.html/

REFE/RL. 2018. “Uzbek Singers Are Told: No Tattoos, No Earrings, and No Singing in Bedrooms in Videos,"February 15. https:// www.rferl.org/a/uzbekistan-musicians-rules-tatoos-earrings-drug-alcohol/29042373.html/

Ringmar, Erik. 2002. "The Recognition Game: Soviet Russia against the West." Cooperation and Conflict 37 (2): $115-136$.

Rich, R. 1993. "Recognition of States: The Collapse of Yugoslavia and the Soviet Union." European Journal of International Law 4 (1): 36-65.

Safarov, M. 2006. "West Authors 'Colour Revolutions'-Uzbek Analyst." BBC Monitoring Central Asia, February 20. Accessed August 2012. Nexis.com.

Selezneva, L. 2002. "Post-Soviet Russian Foreign Policy: Between Doctrine and Pragmatism." European Security 11 (4): $10-28$.

Sharapova, S. 2003. "The U.S.-Western Europe-Russia Triangle and Central Asia." Central Asia-Caucasus 1 (19). Accessed October 19, 2017. https://www.ca-c.org/journal/2003/journal_eng/cac-01/08.shaeng.shtml

Sharapova, S. 2013. "The Intellectual Life of the Heartland: How Mackinder Travelled to Uzbekistan." In Central Asia in International Relations: The Legacies of Halford Mackinder, edited by N. Megoran and S. Sharapova, 171-196. London: Hurst.

Slezkine, Y. 1994. "The USSR as a Communal Apartment, or How a Socialist State Promoted Ethnic Particularism." Slavic Review 53 (02): 414-452.

Spechler, M. 2008. The Political Economy of Reform in Central Asia: Uzbekistan under Authoritarianism. London: Routledge.

Spechler, D., and M. Spechler. 2009. “Uzbekistan among the Great Powers." Communist and Post-Communist Studies 42 (3): 353-373.

Stalin, J. 1913. Marxism and the National Question. Accessed April 2014. https://www.marxists.org/reference/archive/stalin/ works/1913/03.htm

Strömbom, L. 2014. "Thick Recognition: Advancing Theory on Identity Change in Intractable Conflicts." European Journal of International Relations 20 (1): 168-191.

Talbott, S. 1997. "A Farewell to Flashman: American Policy in the Caucasus and Central Asia." July 21. http://www.state. gov/1997-2001-NOPDFS/regions/nis/970721 talbott.html

Teles Fazendeiro, B. 2017a. "Uzbekistan's Defensive Self-Reliance: Karimov's Foreign Policy Legacy." International Affairs 93 (2): 409-427.

Teles Fazendeiro, B. 2017b. Uzbekistan's Foreign Policy: The Struggle for Recognition and Self-Reliance under Karimov. London: Routledge.

Thorun, C. 2009. Explaining Change in Russian Foreign Policy: The Role of Ideas in Post-Soviet Russia's Conduct towards the West. London: Palgrave.

Tolipov, F. 2009. "Strategic Friction in Afghanistan and Geopolitical Reversal in Central Asia." Central Asia-Caucasus 2 (56): 44-52.

Tsygankov, A. 2012. Russia and the West from Alexander to Putin: Honor in International Relations. Cambridge: Cambridge University Press. 
Tsygankov, A. 2015. "Vladimir Putin's Last Stand: The Sources of Russia's Ukraine Policy." Post-Soviet Affairs 31 (4): $279-303$. Tsygankov, A. 2016. Russia's Foreign Policy: Change and Continuity in National Identity. Lanham, MD: Roman and Littlefield. Tucker, J. A. 2007. "Enough! Electoral Fraud, Collective Action Problems, and Post-Communist Colored Revolutions." Perspectives on Politics 5 (03): 535-551.

Usmanov, L. 1994. “Will the 'Islamic Factor' Determine Uzbekistan's Future?" Nezavisimaya Gazeta, January 6, 3.

US Embassy. 2005. "Press Release: Senators McCain, Sununu, and Graham Visit Uzbekistan," May 29. http://uzbekistan. usembassy.gov/pr-052905.html.

Walker, E. 2003. Dissolution: Sovereignty and the Breakup of the Soviet Union. Oxford: Rowman and Littlefield.

Wendt, A. 2003. "Why a World State is Inevitable." European Journal of International Relations 9 (4): 491-542.

White, S., and V. Feklyunina. 2014. Identities and Foreign Policies in Russia, Ukraine and Belarus. New York, NY: Palgrave.

Winrow, G. M. 2001. "Turkey and Central Asia."In Central Asian Security: The New International Context, edited by Roy Allison and Lena Jonson, 207-208. London: Brookings Institution Press.

Wolf, R. 2011. "Respect and Disrespect in International Politics: The Significance of Status Recognition." International Theory 3 (01): 105-142.

Yeltsin, B. 2000. Midnight Diaries. London: Phoenix. 